\title{
Ischemic Myocardium Percentage
}

National Cancer Institute

\section{Source}

National Cancer Institute. Ischemic Myocardium Percentage. NCI Thesaurus. Code C80494.

Percent of the myocardial tissue estimated to exhibit characteristics of inadequate blood flow (ischemia). This is usually determined using a functional study (e.g. MRI, SPECT or PET). 